\title{
WHEN DOES A NEWBORN DEMOCRACY FAIL? EVIDENCE FROM SOUTH KOREA'S SECOND DEMOCRATIC REGIME, 1960-1961
}

\author{
Inhye Heo* \\ Department of Ethics Education, Chonbuk National University, 315 Jinsoo-dang, \\ 567 Baekje-daero, Deokjin-gu, Jeonju-si, Jeollabuk-do, 54896, South Korea \\ E-mail: inhyeheo@jbnu.ac.kr
}

Published online: 15 July 2019

To cite this article: Heo, I. 2019. When does a newborn democracy fail? Evidence from South Korea's second democratic regime, 1960-1961. International Journal of Asia Pacific Studies 15 (2): 31-57, https://doi.org/10.21315/ijaps2019.15.2.2

To link to this article: https://doi.org/10.21315/ijaps2019.15.2.2

\begin{abstract}
This paper aims to discuss when a newborn democracy fails to develop itself towards consolidation, by examining a case of South Korea's second democratic regime launched in 1960. This regime offers an interesting case to study since it lasted only about a year despite active democratic reforms. This paper argues that, for democratic consolidation to succeed, a newborn democracy should be sustainable, which can be attained through the efforts of both government and civil society to enroot democratic norms in their country. This requires more than just an enhancement of the level of democracy via institutional efforts. This paper presents a theoretical framework that highlights the tasks necessary for both government and civil society to make a newborn democracy sustainable. Per this framework, it examines the Korean case and discovers that both the government and civil society in 1960 negated those tasks. Finally, it concludes with implications in the light of the appearance of many newborn democracies in the late twentieth century that have followed bumpy roads towards democratic consolidation.
\end{abstract}

Keywords: Newborn democracy, sustainable democracy, democratic norms, government and civil society, South Korea's second democratic regime 


\section{INTRODUCTION}

When does a newborn democracy fail? To avoid becoming a failed democracy and lead it towards consolidation, what are the foremost tasks that political and social actors of a newly democratised country should undertake? This paper aims to answer these questions by analysing the case of South Korea's second democratic regime, which launched in 1960 in response to peoples' strong yearning for democracy, but experienced "sudden death" (Schedler 1998) in 1961.

Many newborn democracies appeared in the latter half of the twentieth century in Asia, Africa, and Central and Eastern Europe, owing to the great wave of decolonisation and the end of the Cold-War. After this transition, to consolidate their newborn democracies, these countries promoted changes and the development of political processes that are referred to as "democratic reforms" (Lee 2007). Thanks to these reforms, many countries have achieved a minimal definition of democracy, holding regular, free and fair elections. Despite this, they have followed bumpy roads towards democratic consolidation, having shown weaknesses in effective checks and balances of government leaders, the expansion of democratic values, and the effective integration of citizens' opinions as policy input factors, among others. Moreover, several countries are at risk of a reversal in reforms that could lead to the premature collapse of democracy (Hopkin 1999). Further, as a result of governments' poor economic performance, underdeveloped party and parliamentary politics, and overdependence on a few charismatic individuals, political instability in some of these countries is rising. Thus, there is scepticism about whether newborn democracies can be stabilised (Elster et al. 1998; Kapstein and Converse 2008; Converse and Kapstein 2008).

In this context, South Korea (henceforth, Korea) is an important case providing significant implications regarding consolidation of newborn democracies. Emerging shortly after World War II, Korea was a representative newborn democracy in Asia. However, it was unable to stably develop a system of democracy, as three democratic regimes appeared over the course of about seven decades.

The first democratic regime was the First Republic, launched in 1948. It was established through a general election held under the surveillance of the United Nations (UN) Temporary Commission. Through Korea's constitutional Article 1, it was made clear that the country was a democratic republic. This article was defended with the assistance of UN forces during the Korean War (1950-1953). Yet, this democratic regime slowly turned into an authoritarian 
one owing to suppression of the National Assembly and civil society by President Rhee Syngman. It ultimately collapsed in April 1960 as a result of citizen resistance.

Korea's second democratic regime was Heo Jeong's interim government (27 April 1960-14 June 1960), which appeared shortly after President Rhee stepped down, followed by the Second Republic (15 June 1960-16 May 1961), a parliamentary government system led by Prime Minister Chang Myun. However, this second democratic regime collapsed in just a year because of Park Chung-hee's military coup. During the Third and Fourth Republics led by President Park, citizens' political rights were systematically restricted by the over-bureaucratised administration (Enberg and Ersson 2001). Authoritarian rule continued under the Fifth Republic, which emerged from a military coup following Park's death in 1979. However, in striving for survival, civil society established a large pro-democracy coalition-which included students, labourers and middle-class people - to threaten the regime. As a result, a third democratic regime was born in 1987 after the ruling forces accepted the opposition's demands for democracy.

Among these three democratic regimes, this study focuses on the second democratic regime - namely, the interim government and the shortlived Second Republic. This regime tried to develop a democratic system by promoting reform projects. In particular, at the time, the main democratic reform was to revise the constitution, which included reshuffling the forms of government and punishing people involved in corruption during the First Republic. Despite the reform, the regime collapsed in about a year, and as mentioned above, a military coup was the direct cause of its early collapse (Han 1983; Lee 1994; Baek 1999; Moon 2005; Kim 2008).

Political instability and social confusion occurring in the context of a newly democratised country, and the subsequent continuation of unstable democracies, might cause political changes, such as interventions by the military or democratic regression (Armony and Schamis 2005). This implies that Korea's second democratic regime was unable to sustain its newborn democracy against the military, which constituted the anti-democratic forces at that time. This further suggests that, if democracy had been stably settled as a strong guiding principle, both within the government and civil society ${ }^{1}$ at that time, the military coup might not have occurred, or it might not have brought about the end of the regime. In that vein, a few analyses of the Second Republic have provided the foundation for an old argument in Korean political history, namely "the theory about failed democracy," which suggests that a weak democracy invites a coup. Relevant studies include analyses of 
factional disputes in the ruling party and ineffective leadership that is unable to control them, the government's weak policy skills, the innate problem of weak executive power that the parliamentary system had newly introduced (Han 1983), and the lack of political and administrative infrastructure, which Huntington (1965) stressed as a crucial factor of political development (Han 1983; Oh 2007). In particular, Han (1983) highlighted the government's inability to control social confusion, which arose due to ideological conflicts and public discontent with the government's reform, subsequent withdrawal of support from liberal forces that cherished liberal democratic ideals, and radical forces that stressed the end of anti-communism as crucial factors that affected the collapse of the regime. Thus, the previous studies are meaningful in that they elaborated on the political factors that affected the sudden death of the second democratic regime; yet, they do not fully demonstrate the factorseither in the political sphere or the social sphere - that hindered the regime's survival and its development towards democratic consolidation.

In this context, based on the analysis of evidence from Korea's second democratic regime, this paper argues that, for democratic consolidation to succeed, a newborn democracy should be sustainable, which can be achieved through the efforts of both the government and civil society to enroot democratic norms in the country. This task requires more than a mere enhancement of the level of democracy via institutional efforts including democratic reform projects.

Thus, the next part of this paper theoretically elaborates the tasks that both government and civil society actors should undertake to make a newborn democracy sustainable through the implementation of democratic norms. Based on this theoretical discussion, the central part of this paper closely examines the Korean case and discovers that the government and key actors in society in 1960 acted against the tasks necessary for making a newborn democracy sustainable. Lastly, per the research findings, this paper concludes with some implications for newborn democracies.

\section{MAKING NEWBORN DEMOCRACY SUSTAINABLE: TASKS FOR GOVERNMENT AND CIVIL SOCIETY}

Authoritarian regimes, through which most newly democratised countries transitioned, are highly likely to be threatened by two conflicts. According to Svolik (2012), the first is the conflict between rulers and the ruled, while the second involves political conflicts among those who share power. 
When authoritarian regimes lose the ability to maintain control because such conflicts remain unresolved, some of them have the chance to form a newly democratised government, although, in some cases, there remains the possibility that they will have to face undemocratic forces to assume power (Przeworski et al. 2000). When this happens, the new government embarks on a process of consolidating democracy. Most intend to accomplish this task by promoting democratic reform projects focused on introducing new democratic institutions. During this process, they aim to expand the democratic principle of "inclusion"-namely, that all members of the polity should have equal decision-making influence (Young 2002) - which is the opposite of authoritarian governmentality aimed at excluding anyone who might threaten the regime from political processes. This task is urgently required since antidemocratic forces might pose challenges to the new regime (Pevehouse 2002), which could halt reforms or restore authoritarian rule.

Various twentieth-century cases of newborn democracies show that democratic reforms based on the principle of inclusion can vary depending on the context of a given country. In Argentina, for example, Raúl Ricardo Alfonsín's Union Civica Radical government-which appeared in 1983 following the collapse of the military regime - focused on institutional reform to eradicate human rights violations and military political interventions. In Brazil, President Fernando Collor de Mello, who was elected under the democratic constitution, focused on restricting government and protecting citizens' basic political rights. Indonesia, which underwent democratisation in the late 1990s, conducted rapid decentralisation to solve the problem of "rich provinces and poor people" - a situation in which resource-rich regions were subjected to economic and bureaucratic exploitation (Butt 1969)- to respond to public dissatisfaction with the previous centralised system (Shah and Thompson 2004). All of these reform processes involved expanding "inclusion," albeit in different ways depending on the context of each country.

In general, such democratic reform projects via institutional efforts are expected to have positive effects for newborn democracies. Specifically, reform projects intended to eradicate remnants of the past regime institutionally might easily garner public support. Moreover, as Nelson (1995) suggests, a democratic government's reforms based on public support improve the government's ability to cope with anti-democratic forces that refer to illegal activities that might overthrow the new regime.

Yet, democratic reform projects may not always produce positive effects for newborn democracies, as they introduce new institutions that are based on the democratic spirit. These institutions are sticky and resilient 
(Stubbs 2009). Thus, in newborn democracies, newly introduced institutions may have conflicting relationships with the status quo of previous institutions that dominated peoples' actions for a long time. For example, even though a newly democratised government may declare that it will faithfully follow a democratic way of wielding its political power, it may still produce various kinds of political instability related to the old practices of the authoritarian legacy, such as abuse of executive power or the overheated competition of political elites to maximise votes by bribing voters. Interest groups, which are expected to lose previous vested interests due to the introduction of new systems, may resist reform measures. Moreover, citizens who experience the sudden expansion of post-authoritarian freedom are likely to have limited awareness of the expanded responsibility that comes with freedom and produce social confusion. Some of them may wish to see a quick dismantlement of the previous system, aggressively attack the government without public rationale, and aim for radical reform (Ma 2016). However, unlike revolutions, reforms are conducted by actors within regimes through legal procedures; thus, the processes and results might not satisfy the public's expectations and could possibly generate various types of social complaints. Finally, in the context of a newborn democracy, introducing democratic institutions in the name of democratic reform might bring about unexpected ill effects as it develops towards the consolidation of democracy.

Here, the "consolidation of democracy" is quite an extensive idea. From a negative viewpoint, democratic consolidation can be considered successful when newly democratised governments prevent their erosion (Schedler 1998) and project democratic rules as "the only game in town," where no one attempts to overthrow the regime (Linz and Stepan 1996). In comparison, from a positive viewpoint, democratic consolidation can be considered successful when citizens actively support democratic systems, believing they are best for securing high levels of government responsibility, and internalise democratic norms (Im 2000). Despite diverse views on the consolidation of democracy, these discussions are founded on the idea that a newborn democracy is less likely to return to authoritarian rule when it endures for as long as it can (Gerring et al. 2005).

Thus, a newborn democracy can be expected to develop towards democratic consolidation when it gains sustainability. What should be noted here is that "sustainability of democracy" should be differentiated from "level of democracy." The level of democracy can be enhanced through an elaboration of institutional settings, for example, democratic reform projects, but this does not guarantee a newborn democracy's sustainability. The fact that 
Weimar Germany failed to sustain its democracy when democratic norms did not take root, despite having established a high level of democracy through its democratic constitution (Granato, Inglehart and Leblang 1996: 680), directly supports this.

In this context, this paper argues that the foremost step towards democratic consolidation of a newborn democracy is to make it sustainable enough to gain sufficient power to overcome any backlash that might bring about the premature collapse of its fledgling form. This requires the enrooting of democratic norms. Norms, in general, are regarded as values possessing everlasting importance, even though the ways of formulating them and their characteristics vary according to the category - for instance, legal or socialto which they belong (Hetcher and Opp 2001). Norms affect actors' activities and their interactions by "prescribing" and "proscribing" their behaviours in specific circumstances (Hetcher and Opp 2001). Norms provide an answer to the question: "How should we live?" Thus, they guide actors to live better lives (Yoo 1995), even as they control the occurrence of certain outcomes by constricting those behaviours of actors that go against a norm; by doing so, they contribute to the sustenance and development of a specific system.

In this context, democratic norms are values that are required to sustain and develop the democratic system of a given country. In other words, when these norms are enrooted in a country, its democratic system can easily gain the power to sustain and develop itself. In addition, the government and civil society actors responsible for "enrooting democratic norms" are within the system.

First of all, the democratic norm that a newly democratised government should pursue to make democracy sustainable is the democratic legitimacy of the new regime and the relevant activities required to achieve it. Representative governments possess power that has been delegated to them to secure the principle of popular sovereignty by addressing people's will; thus, they cannot function if they do not continue to enjoy democratic legitimacy. This objective cannot be expanded and enhanced only by the minimalist definition of democratisation - introducing democratic rules to select a ruler in a competitive way (Przeworski 1999). The legitimacy of a democratic government means more than the social acceptance of its authority because democratisation occurs due to people's expectation that democracy corresponds to the principle of justice that considers that the interests of all individuals are equal (Dahl 1989). Thus, it is important to focus on a normative understanding of legitimacy that considers the acceptability of authority (Dingwerth 2007). 
Yet, the newly democratised government might have difficulties building legitimacy (Kapstein and Converse 2008) by earning approval, because approval for the government can only be attained and increased when it shows a high level of responsibility. Here, government responsibility includes not just responsibility for its past actions (Manin, Przeworski and Stokes 1999), but a lot more.

First, government responsibility requires effective performance. As public satisfaction largely depends on expectations and perceptions regarding what the government offers (Petrovsky, Mok and León-Cázares 2017), ineffectiveness cannot develop legitimacy (Huntington 1991) because it hardly satisfies citizens. In particular, considering that people in newly democratised countries have a strong tendency to view democracy in terms of prosperity, peace and stability, different from people living in established democracies (Pietsch and Clark 2015), sharing government performances with citizens is an important responsibility.

Second, responsibility requires consistency of government. When government decisions are consistent with the actions or statements that the government has made, it can be considered predictable by its citizens (Mair 2009), thus projecting responsibility.

Third, responsibility requires accountability by making the government-including government employees, bureaucrats and elected officials - answerable to the public. Although responsibility frequently boils down to accountability, there is a difference because accountability cannot be separated from answerability (Heywood 2000), which means making elected politicians and bureaucrats responsive to the public.

Simultaneously, civil society actors should pursue democratic norms to make a newborn democracy sustainable. The development of civil society (Munck 2009) and the degree of social cooperation and integration within it are considered the key values of a democratic regime. In addition, even though the government manages civil society by making basic rules for all associated activities (Walzer 1991), experiences of democracy can be expanded and enhanced by civil society groups. Thus, civil society actors should acknowledge the "prescribing and proscribing" function of norms and make an effort to learn and practice them, while rejecting behaviours that go against them. Specifically, norms include: the ability to participate in public reasoning and deliberation; a spirit of tolerance, cooperation and compromise (Walzer 1974; Macedo 2000); and citizens' practices to implement them. 
Democratic norms can be a dependent variable in relation to the process of procedural democratisation - introducing free and fair electionsin combination with a minimum set of civil and political liberties (Uhlin 2002). This is because learning and practicing democratic norms requires an institutional foundation that teaches and guides actors in both government and civil society about what the norms are and why they should be pursued. However, in relation to the process of creating sustainable democracy, democratic norms can be regarded as an independent variable; this is because the young democracy might be threatened by undemocratic forces unless norms are actively accepted and performed by actors.

When government and civil society actors faithfully accomplish the tasks discussed above, they gain the ability to influence and complement one another and contribute to making their newborn democracy sustainable. For example, the government can enhance peoples' satisfaction with democracy and attract their trust and support by making efforts to enroot the democratic norms of democratic legitimacy. Civil society actors can rationally check the government by learning about the importance of monitoring it and deliberating with other actors with differing opinions when they make efforts to implement the democratic norms of various kinds of civic virtues.

Figure 1 shows that the key to leading newborn democracies towards democratic consolidation is to make them sustainable by enrooting democratic norms so that they can gain sufficient power to overcome the anti-democratic factors in political and social spheres. This requires the following tasks to be undertaken by both the government and civil society: (1) building legitimacy by gaining approval with a high level of responsibility - which requires effective performance, consistency and accountability of government actions; (2) promoting public learning and the practice of newly introduced democratic norms and values; and (3) establishing cooperative contributions of the government and civil society to make the newborn democracy sustainable.

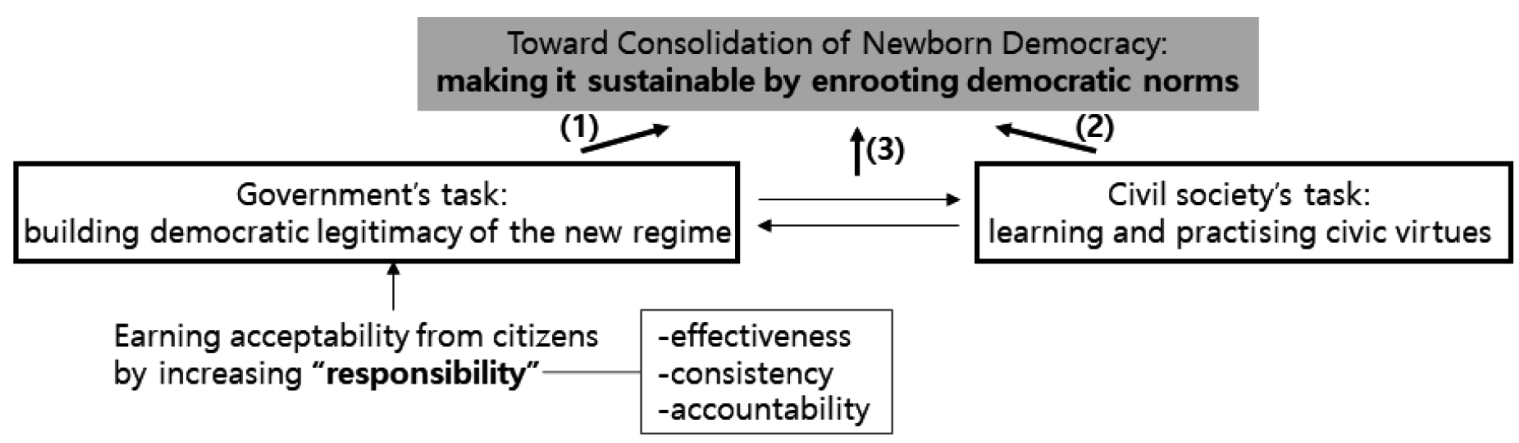

Figure 1: Tasks to be undertaken by government and civil society to make a newborn democracy sustainable. 


\section{AUTHORITARIANISATION OF THE FIRST REPUBLIC AND THE ESTABLISHMENT OF THE SECOND DEMOCRATIC REGIME}

The First Republic that adopted modern democratic politics in Korean history advocated a presidential system and pursued liberal democracy. Yet, the actual distribution of power gradually strayed from one that was prescribed by the constitution and deteriorated into authoritarianism, beginning with a constitutional amendment in 1952. The first constitution of Korea, established in 1948, prescribed that the president be elected from the National Assembly, indirectly by the people (Constitutional History Materials 1968). Yet, the amendment changed presidential elections from being indirect to direct, thus allowing the president to be elected by citizens, which was undemocratic in three ways.

First, it promoted the continuation of the Rhee government. The first National Assembly of Korea consisted of conservative pro-Rhee legislators, including those from the right-leaning National Association (55 seats out of 200 seats), the One-nation Party (29/200) and pro-Rhee independent legislators (29/200) (Gil 1996). Yet, the second general election was characterised by an increased number of elected left-leaning politicians, while pro-Rhee members only occupied 56 seats. This implied that it would have been difficult for Rhee to be elected through an indirect election. To overcome this, he neutralised the National Assembly using his right to dismiss the Prime Minister and Cabinet members (Shin 2000; Cho 2006) and tried to revise the constitution to introduce direct elections.

Second, the executive power that was invested in Rhee's government during the constitutional amendment was illiberal. To obtain National Assembly approval for a bill to amend the constitution in 1952, he proclaimed martial law in Busan, the provisional capital during the Korean War (1950 1953), and arrested lawmakers who opposed the bill.

Third, the amendment violated constitutionalism. Representative democracy begins with the assumption that political elites may go against their principals by making laws favourable to them or special interest groups. It is therefore based on the belief that such one-sidedness should be restrained by a supreme constitution (Hardin 2003). Accordingly, a constitution should secure autonomous power to regulate and manage actor activities, and develop credibility by overcoming institutional weakness (Kapstein and Converse 2008) by securing "institutional time" (Giddens 1984). In this sense, attempting to revise the constitution four years after its enactment shows that the Rhee government did not consider the values of constitutionalism important. 
In this context, social groups demanding democratic political development had been on the rise since the mid-1950s. In particular, many citizens - who had learned about democracy through the education system introduced by the United States military, which ruled Korea from 1945, when the country was liberated from the Japanese colonialism, until 1948 - saw many gaps between reality and the ideal. Scholars raised these issues as well. Founded in 1953, Sasang-gye, a journal widely supported by intellectuals, but severely criticised President Rhee.

Rhee's sick nationalism whose characteristics are heroism, irrationality, and exclusiveness thinks [of] one leader's opinions, instead of millions of people's views, as truth. Tyranny of the ruling party can be so harsh... bewildered by ambition and fame... exposed one-party dictatorship (Chang 1960).

Public complaints and criticism by intellectuals weakened the Rhee government's hegemony, which was confirmed in the election results. In 1956, Lee Gi-bung, a vice-presidential candidate of the ruling Liberal Party, was defeated in the election. In the fourth general election held in 1958, the ruling party won 42.1 percent of the vote, and the opposition Democratic Party had a strong showing at 34.2 percent. ${ }^{2}$ Such results dampened the prospects for the regime's continuation.

In this context, to keep their political power, President Rhee and his party planned to regain power within the framework of elections, which were the minimum means of securing procedural legitimacy. President Rhee undertook large-scale vote rigging to help the vice-presidential candidate win on 15 March 1960 (known as the 3.15 Election), although his election as president became clear as the opposition presidential candidate suddenly died. This election fraud gave rise to severe public resistance in April 1960 (known as the 4.19 Revolution), resulting in President Rhee's retirement and the establishment of Korea's second democratic regime.

\section{THE SECOND DEMOCRATIC REGIME'S DEMORATIC REFORM: CONSTITUTIONAL AMENDMENTS}

After the authoritarian First Republic collapsed, the key democratic reform project with which the National Assembly proceeded was the amendment of the constitution. A constitution is important for supporting a regime's legitimacy since it states the country's goals; clarifies the legitimate means 
to achieve them; and prescribes how political power should be distributed and executed and how conflicts among representatives should be resolved (Persson and Tabellini 2005). Moreover, a constitution is intended to protect and promote citizens' political and civil rights (Brennan 1976) by preparing countermeasures against the possibility of the state invading peoples' rights because the state is a political organisation that upholds a monopoly on the legitimate use of physical force in a given territory (Vendergeest and Peluso 1995). Thus, the amendment of the First Republic's constitution, when authoritarianism occurred, cannot only be seen as a key democratic reform project of the second democratic regime in Korea.

Based on this context, the National Assembly Emergency Measure Committee declared an amendment to the previous constitution right after President Rhee issued his retirement statement on 26 April 1960. The National Assembly argued that it would strengthen citizens' political and social rights by prohibiting censorship on their rallying, associating, publication, etc. Most of all, it stressed a need to change the distribution of political power, as indicated in the following:

Power gives birth to power and power is concentrated on power, leading to the appearance of a one-man dictatorship extending for up to 12 years. We have no other choice than to revise the constitution in a way that adopts the parliamentary system, in order to prevent the concentration of power, to take responsibility for people, and to reflect public opinions in national affairs (Lee 1999).

The statement shows the National Assembly members' strong perception of the need to reduce the president's authority by reshuffling the form of government. Thus, the key to the new constitution that was passed by the National Assembly on 16 June 1960 was to change the previous presidentialism to a parliamentary system and operate bicameralism. Additionally, to reduce the authority of the president, the right to take emergency measures with almost the same effect as law and to appoint government employees was abolished. Moreover, presidential rights regarding amnesty, commutation and reinstatement, as well as the right to proclaim martial law, were changed to follow the Cabinet's decision (Kim 2009).

Furthermore, the new government had to punish individuals and groups who were involved in various forms of corruption during the First Republic. This project targeted two major groups. One included those involved in vote rigging in the 3.15 Election as well as political hoodlums - those involved in a conspiracy to overthrow the opposition Democratic Party and people who 
fired at demonstrators. The other group included businesspeople who provided political funds to the government and engaged in rent seeking during the First Republic.

To this end, at first, Heo Jeong, who led the interim government, referred people involved in election fraud to court and the prosecution. Heo also set a surrender period from 1 June to 20 June 1960 for those who made fortunes by illegal means, announcing on 2 July that those who returned such illegal wealth to the government would be exempt from criminal liability (Dong- $A$ Daily 24 June 1960). Following this, the Chang Myun government of the Second Republic worked to punish those involved in corruption.

Yet, during this process, the Chang government faced strong criticism from the public - including college and high school students, radical groups that wanted to end anti-communism in Korea, and labour unions that intended to enhance their rights to employment and wages (Son and Chung 1996) regarding its will to reform when the Seoul District Court only sentenced one person out of nine to death when the public demanded that all be given the death sentence (Kim 2008). Public resistance reached a climax when students broke into the National Assembly building and occupied the speaker's podium on 11 October 1960, demanding the enactment of special laws to punish those involved in corruption cases of the First Republic (Jeong 1985). This event led the government to promote the second constitutional reform, and four special laws were promptly passed on 23 November 1960. These special laws included disfranchisement of anti-democratic actors' citizenship, punishment of people for election fraud, a retrospective bill to punish illegal fortune makers, and the establishment of a special court and prosecutor (Lee 1999).

Thus, Korea's second democratic regime attempted two reform projects to change the distribution of power of the past authoritarian regime and to punish vote rigging and illicit wealth through constitutional amendments. These reforms were expected to play positive roles in the country's newborn democracy.

\section{FAILED PROCESS OF MAKING THE NEWBORN DEMOCRACY SUSTAINABLE}

According to the theoretical discussion of this paper, government and civil society should make efforts to enroot democratic norms in the country. These efforts include the government's attempts to develop the legitimacy of the new regime and social actors' active learning and practice of newly introduced civic virtues. When these processes take place, each of their efforts gains the 
ability to influence the other; all of them can contribute to the sustainability of a newborn democracy. Yet, from 1960 to 1961 in Korea, efforts of the government and key social actors to accomplish such tasks were rarely found.

What should be noted here are the conflicting views about the existence of an autonomous civil society that has the power to accelerate democratisation in the context of low socio-economic development. In general, according to the experiences of the West, it is conventional wisdom to regard civil society as a product of the development of capitalism (Pelczynski 1984). Yet, although a country displays an extremely low socio-economic developmental level, civil society actors in that country may have autonomy to promote democratic development. This is manifested in the Korean experience-for example, the 4.19 Revolution discussed previously. In 1960, in Korea, industrialisation based on capitalism was extremely weak and peoples' lives were almost totally dependent on services offered by the government. However, the Korean people ended the undemocratic regime through peoples' collective protests, which signified that a civil society that had the autonomy to develop democracy was formed in Korea around 1960. Thus, both the government and social actors at that time had the potential to make their newborn democracy sustainable.

\section{The Government's Failure}

The newly democratised government failed to develop the legitimacy of the new regime. This is supported by the fact that the government's activities went directly against establishing those factors-effectiveness, consistency and accountability - that enhance government responsibility and contribute to the enhancement of the regime's legitimacy.

First, the administration and Parliament of the second democratic regime failed to show effective performance. This is manifested by severe factional conflicts within the ruling Democratic Party and frequent government reorganisations that produced extreme political instabilities. After the first constitutional amendment, the Democratic Party accelerated the power struggle in the new institutional setting created by the new parliamentary system, which specified that the Prime Minister is the head of the Cabinet, and Cabinet members are appointed by the Prime Minister to be independent of the administration and legislature. At the same time, members of legislatures could become Cabinet members. ${ }^{3}$

In this context, when electing the Prime Minister, a conflict erupted between the old and new factions of the ruling Democratic Party. Those factions did not show conflicting relationships during the First Republic since the members of the party, established in 1955, had focused their 
activities on protecting liberal democracy against the authoritarianism of the Rhee government, stressing its identification as "a party that protects the constitution." Thus, during the First Republic, both old and new factions of the party had a common goal. Yet, after the collapse of the Rhee government, each faction transgressed the general characteristics of factions - a group with high degree of cohesiveness based on shared ideas and values - and showed characteristics of a disruptive group that takes all possible measures for vast amounts of interest (Yang 2000). Specifically, after the general election was held on 29 July 1960, the new faction organised a 13-person committee with exclusive rights to nominate presidential and prime ministerial candidates, and it proposed Chang Myun for Prime Minister. The old faction, meanwhile, recommended Kim Do-yeon. President Yoon Bo-sun nominated Kim Do-yeon, who belonged to the old faction, but Kim was rejected in the parliamentary vote, and Chang of the new faction was appointed Prime Minister. The old faction strongly resisted this and formed a separate party on 20 August, determined to punish old faction members who moved to the new faction (Han 1983).

These factional conflicts led to frequent government reorganisations. Government reorganisation comprises a readjustment of government functions, including the integration, separation and establishment of ministries, as well as the changing of the heads of each ministry based on governing philosophies and blueprints for state management. As such, government reorganisation is a task that should be approached carefully, for it involves a restructuring process that deliberately changes the properties of the existing system (Heo 2017). However, the government reorganisation of 1960-1961 was not approached carefully, since it was employed as a means to deal with complaints among the old and new factions of the ruling party, which led to severe political instabilities. To win the election, Prime Minister Chang once insisted on forming a pan-national Cabinet, but later broke his promise and formed a Cabinet mostly comprising members of his new faction, angering the old faction. Facing protests from the old faction, Chang demanded resignations from the Chief Secretary, National Defence Minister, Commerce Minister, and Home Minister just two weeks after the Cabinet was formed. After that, Chang began to negotiate with the old faction, who wanted to fill the vacant Cabinet posts with their people. In addition, the young group, isolated from the Democratic Party leadership, pressed the Prime Minister to reshuffle the Cabinet again and drove out members from the old faction (Kim 2010; Kang 2009; Jeong 2012). Reshuffling occurred so frequently that people spread the rumour that anyone who caused trouble were offered positions (Han 1983). 
Considering that these political instabilities were developed in the new institutional setting that the first constitutional amendment offered, the recognition of the amendment by political forces functioned as a key factor affecting the instabilities. For a parliamentary system to be successful and achieve its purpose - namely, that the Parliament and the Cabinet improve political responsibility through mutual dependence - the support of political, cultural or institutional factors is needed (Lijphart 1996). These factors include the development of party politics, clear divisions of responsibility between political decisions and administrative execution, and a mature and self-reflective political culture, among others.

Yet, efforts to revise the constitution were not based on a belief that a constitutional amendment to the parliamentary system would be more advantageous than would be a presidential system for the democratic development of the country. Instead, the amendment resulted from a compromise among political forces' narrow interests. Specifically, with the 3.15 Election close at hand, the old faction of the Democratic Party preferred the parliamentary system because there were no suitable presidential candidates after Cho Byeong-ok - a strong candidate and a leader of the old factionsuddenly died. While the new faction of the party wanted to maintain the presidential system because they had Chang Myun, an influential presidential candidate, the new party could not exercise influence in Parliament due to its insufficient number of seats (Yang 2000). In this situation, the previous ruling party - the Liberal Party - had to fight for its survival, so it agreed to the idea of the Democratic Party's old faction. Thus, constitutional amendment focused on changing the form of government was achieved through an agreement between the old factions of the Democratic Party and the Liberal Party to promote their political interests. In such a context, after the constitutional amendment, the Democratic Party accelerated the power struggle in the new political topography created by the new parliamentary system, thus they were not able to perform effectively as representatives of their citizens.

Second, the government's lack of consistency, which is required to fulfil its responsibility, is clearly found after the second constitutional amendment. As discussed previously, this amendment was aimed to dismantle corruptive legacies of the past regime. Thus, citizens' expectations of broad and strong punishment on people guilty of corrupt activities, including vote rigging of the First Republic, increased (Kyunghyang Daily 20 June 1960). Further, as Han (1983) discussed, this led intellectuals and journalists, who had at first strongly supported the government of the Second Republic for their belief in liberal democracy, to withdraw their support. 
Yet, the result was not acceptable to citizens, largely because the government's statement did not coincide with its actions. For example, among those arrested for vote rigging, 69 were sentenced to short prison terms, four received life imprisonment, and five were sentenced to death. Many others who were arrested were found not guilty (Kyunghyang Daily 9 September 1960). Also, during the period of a statute of limitations from 27 January 1961 to 28 February 1961, out of 14,000 people, only 250 were booked while 180 cases had a suspension of prosecution. These punishments were regarded as moderate by citizens, provoking their strong criticism. They argued that the government and prosecuting authority did not have the will to eradicate authoritarian legacies and acted as a mere formality. This criticism was exacerbated when the prosecuting authority frequently delayed starting investigations and ordered the suspension of prosecution (Kim 2008). Thus, citizen demonstrations led by students, criticising insufficient punishment for people involved in vote rigging, showed the government's lack of consistency.

Third, the lack of accountability is found in the fact that the government failed to be accountable to the people's voices. After the second constitutional amendment, apart from the citizens discussed above, industrialists also protested the punishments dealt to businesspeople who made illegal fortunes, for reasons that were different from those of the citizens. During the early days of reform, some businesspeople who made large political donations, and accumulated wealth through tax evasion, said that they would atone by contributing money to national finances (Dong-A Daily 9 June 1960). Afterward, however, they began to attack the legitimacy of the bill, which is manifested by the statement issued on 4 March 1961 by the Economic Council of Korea:

If this bill passes the Upper House, it will bring confusion to the society and tie business people's hands. We sincerely advise that this bill, which prevents business activities, scatters national capital, and, furthermore, provokes division, not be enacted.... If North Korea never wants to see economic prosperity in South Korea, it can be said that this bill promises the advantage of killing two birds with one stone (Lee 1999).

Facing such resistance from citizens, the government took lukewarm measures, claiming that people had the right to demonstrate (Kyunghyang Daily 9 September 1960). In a similar vein, the government simply "persevered," saying that perfect freedom had to be given to citizens so they would feel disgusted by the disorder caused by that freedom. Yet, responding to resistance from industries, the government partly accepted its demands and conducted 
limited reforms by mitigating its original punishment plan. The Upper House weakened the bill, and as a result, the punishment targets were limited to people who illegally acquired fortunes in connection with the 3.15 Election (Han 1983; Kim 2010).

There are two major reasons why the government had little choice but to accept the industrialists' demands. First, Korea was a capitalist country, and it needed the support of capitalists to secure the regime's legitimacy by continuously accumulating capital. Accordingly, it is inevitable that such a government would be structurally subordinate to capital (Przeworski and Wallerstein 1985). Second, the government desperately needed the cooperation of businesspeople to ensure its economic growth plan was successful. It prepared a five-year economic development plan that aimed to develop a free enterprise system to respect private autonomy and achieve guided capitalist development (Singh 2002) by encouraging the private sector to play an active role. Thus, the government faced a dilemma because it had little choice but to consider easing the punishment of those who illegally made a fortune to avoid adversely affecting the economy (Dong-A Daily 9 June 1960). As Finance Minister Kim Yeong-seon noted:

It is no exaggeration to say that the government hasn't yet started punishing illicit fortune makers. While investigating large illicit fortune makers, including tax evaders, under the tax law, we showed a willingness to check again if there are persons missing in the process. We, however, are trying to find a point of compromise (Kyunghyang Daily 9 September 1960).

The government ultimately decided to restrictively carry out the punishments, though there were attacks during the Lower House plenary session regarding the reasons why the prosecution of illicit fortune makers was being delayed (Kyunghyang Daily 9 September 1960). To many citizens, this restrictive and not full-scale application of the law to tackle corruption harmed the government's accountability.

Lack of accountability is also found at the low rate of bill reflectionthe percentage of bills that are finally reflected in law through deliberation by Parliament. Since the legislative agenda contains promises lawmakers made to citizens during election campaigns, based on public opinion surveys regarding political and economic issues (Peterson 1990; Kessel 2001), bill reflection rates become an indicator of the government response. In particular, in 1960, people called for legislators of the newly democratised regime to lay a democratic foundation (16 percent), establish social welfare (14 percent), 
produce economic achievements (6 percent), abolish dictatorship (5 percent), reunify the country ( 4 percent), promote clean politics ( 3 percent), and eradicate corruption (2 percent) (Yoon 1979: 401; Han 1983: 102). The National Assembly, however, did not respond actively to such demands, as evidenced by the low bill reflection rate under the Second Republic. Table 1 reveals that the rate reached a low of 11.4 percent during the Fifth National Assembly in 1960-1961.

Table 1: Bill reflection rate of the National Assembly for each bill-proposing subject (1948-2016).

\begin{tabular}{lcccc}
\hline Bill reflection rate & $\begin{array}{c}\text { Bills proposed } \\
\text { by legislators }\end{array}$ & $\begin{array}{c}\text { Bills } \\
\text { proposed by } \\
\text { committees }\end{array}$ & $\begin{array}{c}\text { Bills submitted } \\
\text { by the } \\
\text { government }\end{array}$ & $\begin{array}{c}\text { Average bill } \\
\text { reflection rate } \\
(\%)\end{array}$ \\
\hline Constituent National & $35 / 74$ & $24 / 29$ & $109 / 143$ & 68.8 \\
Assembly, NA (1948-1950) & $52 / 124$ & $51 / 77$ & $149 / 215$ & 50.6 \\
2nd NA (1950-1954) & $40 / 113$ & $41 / 57$ & $91 / 239$ & 48.7 \\
3rd NA (1954-1958) & $22 / 93$ & $24 / 31$ & $53 / 201$ & 42.5 \\
4th NA (1958-1960) & $18 / 115$ & $17 / 23$ & $43 / 159$ & 11.4 \\
5th NA (1960-1961) & $18 / 115$ & $17 / 23$ & $43 / 159$ & 38.9 \\
Supreme Council for & $35 / 74$ & $24 / 29$ & $109 / 143$ & 68.8 \\
nation's reconstruction & $78 / 179$ & $63 / 64$ & $255 / 291$ & 76.5 \\
6th NA (1963-1967) & $5 / 11$ & $2 / 3$ & $12 / 35$ & 48.8 \\
7th NA (1967-1971) & $61 / 113$ & $41 / 41$ & $255 / 479$ & 80.5 \\
8th NA (1971-1972) & $3 / 5$ & - & $57 / 124$ & 53 \\
9th NA (1973-1979) & $7 / 7$ & $26 / 26$ & $156 / 156$ & 100 \\
10th NA (1979-1980) & & $40 / 40$ & $279 / 287$ & 78.5 \\
National Security & $64 / 164$ & $29 / 29$ & $104 / 168$ & 70.6 \\
Legislative Council & $90 / 181$ & $101 / 108$ & $355 / 368$ & 80.9 \\
11th NA (1981-1985) & $244 / 462$ & $68 / 69$ & $561 / 581$ & 78.2 \\
12th NA (1985-1988) & $99 / 252$ & $332 / 338$ & $739 / 807$ & 77.7 \\
13th NA (1988-1992) & $349 / 806$ & $250 / 261$ & $551 / 595$ & 79.2 \\
14th NA (1992-1996) & $770 / 1561$ & $647 / 659$ & $880 / 1102$ & 72.4 \\
15th NA (1996-2000) & $2239 / 5728$ & $1012 / 1029$ & $1288 / 1693$ & 69.6 \\
16th NA (2000-2004) & $3866 / 11,191$ & $803 / 1093$ & 69.2 \\
17th NA (2004-2008) & $5346 / 15,444$ & $1280 / 1285$ & & \\
18th NA (2008-2012) & & & & \\
19th NA (2012-2016) & & & & \\
\hline Source: Webste & & & & \\
\hline
\end{tabular}

Source: Website of the National Assembly Information System, http://likms.assembly.go.kr/bill/stat/ statFinishBillSearch.do (accessed 29 April 2007). ${ }^{4}$ 


\section{Failure of Civil Society}

Civil society actors, including students and labourers, during the second democratic regime seemed not to recognise their tasks, such as enrooting democratic norms through learning and practising civil virtues to contribute to making the newborn democracy sustainable, so that it could have enough time to develop towards democratic consolidation. This is found in key features of social demonstrations at that time. Although there is no precise data regarding the number of demonstrations during the Second Republic, it is known that demonstrations led by social actors occurred almost every day, which exacerbated social confusion and disorder.

Specifically, key social actors, who mainly included students, labourers and radical groups that intended to enter institutional politics by cooperating with some of them, largely focused on spewing their demands using the expanded freedom of expression, rather than rationally deliberating their opinions along with other social actors who held different opinions. For example, college students supported by radical groups, including the League of National Unification formed by students from Seoul National University, stressed their opposition to anti-communism and put forward their strong demand to reconcile with North Korea and see the withdrawal of United States Forces. In addition, labourers, including the Teachers' Union, launched nation-wide demonstrations stressing their opposition to the government's intention to legislate the Provisional Special Law on anti-communism and the law on regulating demonstrations, among others. The Teachers' Union dared to mount a hunger strike, which mobilised students to join the demonstrations (Han 1983; Son and Chung 1996).

During this process, citizens, particularly those who strongly opposed the authoritarian President Rhee of the First Republic, focused their attention on the issue of punishing pro-Rhee forces. Beginning in early May 1960, about 10 days after President Rhee stepped down, citizens began to stage large-scale demonstrations, using slogans such as "Punish people involved in vote rigging" and "Recover assets of illicit fortune makers." Because most of these demonstrations were largely based on their distrust of the government's restrictive reforms, they kept arguing that the government had an anti-reformist attitude and identified their protests as "peaceful demonstration" (Kyunghyang Daily 23 March 1961). Although many demonstrations continued in a violent way, police forces who were attacked and criticised by the public because of their service during the First Republic, worked extremely insincerely, and society entered an anarchy-like state (Han 1983). 
Thus, the opinion that claimed that had the government faithfully followed peoples' arguments, this severe social disorder might not have happened (Kyunghyang Daily 13 October 1960) is debatable. Several facts showed that civil society actors did not input sufficient effort to create a space for reasonable discussion to democratically resolve problems through compromise and understanding. For example, many of the protesters used bars to threaten the police and frequently engaged in group disturbances (Kyunghyang Daily 23 June 1961) while the Parliament once considered the enforcement of a law that regulated demonstration, all of which reveal severe social confusion and disorder. In this context, there were demonstrations aimed at stopping protests (Lee 2015).

Thus, it is still debatable whether public fury could have be eased had the government strictly punished people involved in election fraud and widened the scope for prosecuting those who had illegally accumulated wealth. Finally, the social instability of that time shows that the expansion of newly introduced democratic norms and rules - tasks required from civil society to make the newborn democracy sustainable - was not displayed within civil society, which did not contribute to making the newborn democracy sustainable.

\section{CONCLUSION}

The analysis of the Korean case shows that newborn democracies confront crises of failure that hinder development towards a consolidation of democracy when its government and civil society are negligent in their efforts to make the newborn democracy sustainable. Specifically, the analysis showed that during the second democratic regime in Korea, political actors failed to enroot the government's democratic norms and therefore democratic legitimacy, which requires enhanced governmental responsibility. Key social actors also failed to enroot democratic norms that require the learning and practice of civic virtues. In this context, neither their respective tasks, nor their positive influences on each other in making the newborn democracy sustainable could occur, even though the regime was in a favourable position to consolidate the newborn democracy due to the strong antagonism in both the political and social spheres towards authoritarianism experienced during the previous regime.

As per this research finding, this paper is significant in two ways.

First, by analysing the case of Korea, it shows that the foremost task a newly democratised government should undertake is to consolidate its 
newborn democracy to make it sustainable. As discussed earlier in this paper, the clear reason for the early collapse of the regime was the military coup, which occurred in May 1961. Young military officers, who had been members of the national defence guard established in 1946, became the country's elites after receiving United States education and training, which developed their traditional inclinations - namely, security, stability and development (Abrahansson 1972). Moore suggested that when elites who are slightly isolated from the centre of power carry out reforms or start revolutions, they are very likely to succeed (1993). Likewise, those young Korean soldiers were relatively shielded from corruption, as an isolated power within the military succeeded in seizing power. We cannot say that the military coup and the collapse of the regime occurred solely because of political and social confusion. It should be noted that the military initiated a coup to resolve problems within the military and to intervene in politics, disregarding national defence, which was its obligation for external security. ${ }^{5}$ Yet, this paper shows that an unstable democracy bears some responsibility for the sudden collapse of the regime since a stable democracy is the strongest condition for preventing anti-democratic forces in the context of a newborn democracy.

Second, this paper is also significant because it shows ways to consolidate a newborn democracy. By elaborating the theoretical framework and examining the case of Korea, it revealed not only the specific tasks that both political and social actors should engage in, but also the importance of the tasks in promoting democratic development in the context of a newborn democracy. In other words, merely enhancing the level of democracy via institutional efforts including some notable democratic reform projects is not sufficient. Thus, this paper is expected to have implications for and offer insights into many young democracies in the world that are suffering hardships in consolidating their democracy.

\section{ACKNOWLEDGEMENTS}

This work was supported by the Ministry of Education of the Republic of Korea and the National Research Foundation of Korea (NRF2015S1A5B5A02009827) and by research funds for newly appointed professors of Chonbuk National University in 2018. 


\section{NOTES}

* Inhye Heo is an assistant professor of political science at Chonbuk National University, South Korea. She began her academic career at Korea University in 2011, where she was a research professor in the Peace and Democracy Institute. Her research explores the political economy of Asian countries, with a particular focus on public policy studies, democracy and democratic governance. She has published numerous articles on Korean politics and the political economy of Asia. Her recent works include Paradox of Administrative Decentralization Reform in Asian Young Democracies (World Affairs, 2018), Government Reorganization in the Light of Quality of Democracy: South Korea (Asian Politics and Policy, 2017), Overlapping Political Conflicts and Legislative Gridlock (Japanese Journal of Political Science, 2016), Neoliberal Developmentalism in South Korea (Asian Pacific Viewpoint, 2015), and Managing Policy Dilemmas in South Korea (Asian Studies Review, 2015).

1 Webpage of National Archives of Korea (www.archives.go.kr), accessed 3 January 2018.

2 Ibid., accessed 10 October 2017.

3 Webpage of Korea Ministry of Government Legislation (http://www.moleg.go.kr), accessed 15 October 2017.

4 The high bill reflection rates for the 7th, 9th and 11th National Assemblies and the legislative council for national preservation reveal how powerless the Parliament was under the then-authoritarian regime. The number of bills proposed by lawmakers rapidly increased with the launch of the third democratic regime in 1988, indicating that the status of the National Assembly was strengthened and that the government had a strong will to bring about change and reform.

5 Complaints rapidly increased in the military with the surge in the number of soldiers resulting from the mobilisation system and subsequent stagnation in promotions shortly after the Korean War. Therefore, it is possible that military figures staged a coup and overthrew the democratic government to intervene in politics and pursue their personal interests.

\section{REFERENCES}

About demonstration. 1960. Kyunghyang Daily, 13 October. http://newslibrary.naver.com (accessed 13 January 2018).

Abrahansson, B. 1972. Military professionalism and political power. Beverly Hills: Sage.

An interpellation by Lower House. 1960. Kyunghyang Daily, 9 September. http://newslibrary.naver.com (accessed 22 January 2018).

Armony, A. C. and Schamis, H. E. 2005. Babel in democratization studies. Journal of Democracy 16 (4): 113-124, https://doi.org/10.1353/jod.2005.0055.

Attention on marginal line between 'Whan' and 'Won'. 1960. Dong-A Daily, 9 June.

Baek, U.-S. 1999. The truth of setting history straight. Hwang-hae Mun-hwa [Culture] 25: 375-379. 
Brennan, W. 1976. State constitutions and the protection of individual rights. Harvard Law Review 90: 489-504.

Butt, R. 1969. The power of Parliament. London: Constable.

Chang, J.-H. 1960. Sasang-gye: A special issue. Seoul: Dong-bang.

Cho, J.-K. 2006. National competitiveness and reform of political society in Korea. Korean Journal of Political Science 14: 179-206.

Close investigation into corruption. 1960. Dong-A Daily, 24 June.

Constitutional History Materials. 1968. Vol. 5: Minutes on constitutional revision. Seoul: National Assembly.

Converse, N. and Kapstein, E. B. 2008. The threat to young democracies. Survival: Global Politics and Strategy 50 (2): 127-140, https://doi.org/10.1080/00396330802034325.

Dahl, R. A. 1989. Democracy and its critics. New Haven and London: Yale University Press.

Demonstration Shocked the Government. 1961. Kyunghyang Daily, 23 June, http://newslibrary.naver.com (accessed 22 January 2018).

Dingwerth, K. 2007. The new transnationalism. New York: Palgrave Macmillan.

Elster, J. et al. 1998. Institutional design in post-Communist societies: Rebuilding the ship at sea. New York: Cambridge University Press.

Enberg, J. and Ersson, S. 2001. Illiberal democracy in the Third World: An empirical enquiry. In Democracy and political change in the Third World, ed. Haynes, J., 36-56. London and New York: Routledge.

Gerring J. et al. 2005. Democracy and economic growth: A historical perspective. World Politics 57 (3): 323-364, https://doi.org/10.1353/wp.2006.0002.

Giddens, A. 1984. The constitution of society: Outlines of the theory of structuration. Berkeley: University of California Press. https://doi.org/10.2307/2111789

Gil, S.-H. 1996. Political parties and legislative politics of the first Republic of Korea. Journal of Korean Politics 5: 118-142.

Granato, J., Inglehart, R. and Leblang, D. 1996. Cultural values, stable democracy, and economic development: A reply. American Journal of Political Science 40 (3): 680-696, https://doi.org/10.2307/2111789

Han, S.-J. 1983. The Second Republic and democracy in Korea. Seoul: Jongno Books.

Hardin, R. 2003. Liberalism, constitutionalism, and democracy. Oxford: Oxford University Press.

Heo, I. 2017. Government reorganization in the light of quality of democracy. Asian Politics \& Policy 9: 202-221.

Hetcher, M. and Opp, K. 2001. Social norms. New York: Russell Sage Foundation.

Heywood, A. 2000. Key concepts in politics. New York: Palgrave Macmillan.

Hopkin, J. 1999. Spain: Political parties in a young democracy. In Changing party systems in Western Europe, ed. Broughton, D., 207-231. London: Wellington House.

Huntington, S. P. 1965. Political development and political decay. World Politics 17: 386430, https://doi.org/10.2307/2009286.

Huntington, S. P. 1991. The third wave: Democratization in the late twentieth century. Norman: University of Oklahoma Press.

Im, H. 2000. Democracy in the era of globalisation. Seoul: Nanam. 
Jeong, H.-J. 1985. Was democratic government incompetent? Shindong-A, May, http://www .changmyun.com/technote7/board.php?board $=\mathrm{d} 63 \&$ page $=18 \&$ command=body\&no=362 (accessed 6 August 2017).

Jeong, S.-H. 2012. The research on bicameral system in the Second Republic of Korea. Korean Party Studies Review 11: 5-36.

Kang, W. 2009. Revisiting the fall of the Second Republic in South Korea. Journal of Korean Political and Diplomatic History 30: 45-70.

Kapstein, E. B. and Converse, N. 2008. Why democracies fail. Journal of Democracy 19 (4): 57-68, https://doi.org/10.1353/jod.0.0031.

Kessel, J. H. 2001. Presidents, the presidency, and the political environment. Washington, DC: CQ Press.

Kim, B.-W. 2009. History of Korea's constitution and directions for revision of civil rights and civil liberties in current constitution. Public Law Journal 10: 65-95.

Kim, I.-Y. 2010. Korea's national founding and making it rich. Seoul: Guiparang.

Kim, K.-D. 2018. 4.19 \& 5.16. Seoul: Kiparang.

Kim, M.-C. 2008. Taking a look at the investigation into anti-democratic activities. Kirok-in 2: 132-136. http://archives.go.kr (accessed 1 January 2019).

Lee, D.-Y. 2007. Between consolidation and reverse of democracy. The Korean Journal of International Studies 47: 173-196.

Lee, H.-H. 2015. Korean history, 23. Seoul: Chungabooks.

Lee, T.-H. 1994. Diplomacy of the Second Republic of Korea. Journal of Korean Political and Diplomatic History 10: 339-379.

Lee, Y.-W. 1999. The Second Republic of Korea and Chang-myun. Seoul: Bumwoosa.

Lijphart, A. 1996. Institutional design in new democracies. Boulder: Westview Press.

Linz, J. J. and Stepan, A. C. 1996. Toward consolidated democracies. Journal of Democracy 7 (2): 14-33, https://doi.org/10.1353/jod.1996.0031.

Ma, S.-Y. 2016. The space for liberal democracy in South Korea: Political discussions in Sasang-gye during the early 1960s. Journal of Korean Politics 25: 175-200.

Macedo, S. 2000. Diversity and distrust. Cambridge: Vard University Press.

Mair, P. 2009. Representative versus responsible government. Max Planck Institute for the Study of Societies, Cologne. http://www.mpifg.de/pu/workpap/wp09-8.pdf (accessed 10 January 2018).

Manin, B., Przeworski, A. and Stokes, S. C. 1999. Democracy, accountability and representation. Cambridge: Cambridge University Press.

Moon, B.-J. 2005. The Second Republic and "collapsed" democracy in Korea. Democracy and Human Rights 5: 5-37.

Moore, B. 1993. Social origins of dictatorship and democracy. Boston: Beacon Press.

Munck, G. L. 2009. Measuring democracy: A bridge between scholarship and politics. Baltimore: Johns Hopkins University Press.

Nelson, D. N. 1995. After authoritarianism: Democracy or disorder? London: Praeger.

Oh, M.-H. 2007. Republicanism of the Second Republic of Korea. The Review of Korean and Asian Political Thought 6: 55-70.

Peaceful demonstration. 1961. Kyunghyang Daily, 23 March. http://newslibrary.naver.com (accessed 13 January 2018). 
Pelczynski, Z. A. 1984. The state and civil society. Cambridge: Cambridge University Press.

Persson, T. and Tabellini, G. E. 2005. The economic effects of constitutions. Cambridge: MIT Press.

Peterson, M. A. 1990. Legislating together: The White House and Capitol Hill from Eisenhower to Reagan. Cambridge: Harvard University Press.

Petrovsky, N., Mok, J. Y. and León-Cázares, F. 2017. Citizen expectations and satisfaction in young democracy. Public Administration Review 77: 395-407, https://doi. org/10.1111/puar.12623.

Pevehouse, J. D. 2002. With a little help from my friends? Regional organisations and the consolidation of democracy. American Journal of Political Science 46 (3): 611626, https://doi.org/10.2307/3088403.

Pietsch, J. and Clark, M. 2015. Critical citizens: Attitudes towards democracy in Indonesia and Malaysia. Japanese Journal of Political Science 16: 195-209, https://doi. org/10.1017/S1468109915000031.

Przeworski, A. 1999. Minimalist conception of democracy: A defense. In Democracy's value, eds. Shapiro, I. and Hacker-Cordon, C., 23-57. Cambridge: Cambridge University Press.

Przeworski, A. and Wallerstein, M. 1985. Capitalism and social democracy. Cambridge: Cambridge University Press.

Przeworki, A. et al. 2000. Democracy and development: Political institutions and wellbeing in the world, 1950-1990. Cambridge: Cambridge University Press.

Schedler, A. 1998. What is democratic consolidation? Journal of Democracy 9: 91-107. https://doi.org/10.1353/jod.1998.0030.

Shah, A. and Thompson, T. 2004. Implementing decentralized local governance: A treacherous road with potholes, detours, and road closures. Policy Research Working Paper Series, no. WPS 3353, World Bank, Washington, DC.

Shin, W.-C. 2000. A few thoughts on current presidential system. The Law Research Seoul National University 41: 316-343.

Singh, A. 2002. "Asian capitalism" and the financial crisis. In International capital markets systems in transition, eds. Eatwell, J. and Taylor, L., 339-367. Oxford: Oxford University Press.

Son, H.-C. and Chung, H.-G. 1996. Civil society and civic movement during the Second Republic. In The Second Republic and Korean democracy, ed. Paik, Y.-C., 269304. Seoul: Nanam.

Stubbs, R. 2009. What ever happened to the East Asian developmental state? The unfolding debate. The Pacific Review 22 (1): 1-22, https://10.1080/09512740802650971.

Svolik, M. W. 2012. Politics of authoritarian rule. Cambridge: Cambridge University Press.

The main instigator of the vote rigging. 1960. Kyunghyang Daily, 20 June. http://newslibrary. naver.com (accessed 25 January 2018).

Uhlin, A. 2002. Globalization, democratization and civil society in Southeast Asia. In Globalization and democratization in Asia, eds. Jonsson, K. and Kinnvall, C., 149-166. London: Routledge.

Vendergeest, P. and Peluso, N. L. 1995. Territorialisation and state power in Thailand. Theory and Society 24 (3): 385-426, https://doi.org/10.1007/BF00993352. 
Yang, J.-I. 2000. A study on political conflicts between the New Faction and Old Faction of democratic party. Journal of Korean Political and Diplomatic History 21 (2): $113-136$.

Yoo, H.-R. 1995. A study on the contemporary Kantian liberal ethics. Korea Political Science Review 28 (2): 463-490.

Yoon, C.-J. 1979. Political system in Korea. Seoul: Seoul National University Press.

Young, I. M. 2002. Democracy and inclusion. Oxford: Oxford University Press.

Walzer, M. 1974. Civility and civic virtue in contemporary America. Social Research 41 (4): 593-611.

Walzer, M. 1991. The idea of civil society: A path to social reconstruction. Dissent 39: $293-304$. 